\title{
Local Actors' Interest and Negotiation Strategies for Benefits in Ghana's Oil and Gas Sector
}

\author{
Asaah Sumaila Mohammed \\ Department of Community Development, University \\ for Development Studies, Tamale, Ghana \\ Email: asaahuds@gmail.com/masaah@uds.edu.gh \\ DOI//http://dx.doi.org/10.4314/gjds.v16i3.2
}

\begin{abstract}
Since Ghana's oil discovery in 2007, the question of how the resource will benefit affected communities and who holds the responsibly is still a subject of debate. Will the benefits be negotiated by local actors or will benefits flow automatically from the state and oil companies? Guided by the actor-oriented theoretical foundation, the paper qualitatively examines how different actors have emerged in the Western Region of Ghana to negotiate for benefits from the oil find. Two qualitative case studies were conducted on fisher folks and youth groups to examine the processes, dynamics and outcomes of their negotiations. The results show that disenfranchised youth and fisher folks, who feel dispossessed of their livelihood, have resorted to social mobilisation and contentious political bargaining strategies to negotiate for their benefits and to channel their grievances. Alternative livelihoods, jobs for locals and improvement in social infrastructural development are the primary requests of the local actors. The paper concludes that local actors' interests are varied and negotiations are largely unregulated. Local actors constantly accuse oil companies for not prioritising their needs. State coherent policies and structures to mediate the negotiation processes between local actors, companies and the state are therefore recommended to avoid violent conflicts.
\end{abstract}

Keywords: Local Actors, Negotiation, Local Benefits, Oil and Gas, Ghana

\section{INTRODUCTION}

Since Ghana's commercial oil discovery in 2007 and subsequent production in 2010, the local communities along the coast of the Western Region have remained expectant of benefits and commensurate compensation packages (Nkrumah, Aklorbortu \& Suazo, 2008; Bouten, Everaert, Van Liedekerke, De Moor, \& 
Christiaens, 2011; Friedrich-Ebert-Stiftung Ghana, 2011; Obeng-Odoom, 2013; Mohammed, Kpieta \& Owusu-Sekyere, 2014; Owusu, 2014; Owusu \& Boatemah, 2014). Of course, several concerns have been raised by fishing communities along the coast about how their livelihoods are endangered by restrictions imposed on their fishing activities and sea pollution resulting from oil exploration and production(Ackah-Baidoo, 2013; Mohammed et al., 2014). According to Ackah-Baidoo (2013), fisher folks have attributed the proliferation of strange sea weeds which are affecting fishing activities to oil production on the coast of Western Region. Some studies on the socio-economic impacts of the oil find in Ghana indicated high costs of housing and landed properties along the coast of Western Region due to immigration and commercial land acquisition for oil related infrastructure development due to oil exploitation in the region(Edem, 2011; Yalley \& Ofori-Darko, 2012). Undeniably, many oil producing countries experience similar socio-economic challenges as well as severe air, land and water pollution, with disastrous impacts on health and livelihoods (Pyagbara, 2007; Yakovleva, 2011; Ackah-Baidoo, 2013; O'Faircheallaigh, 2013; Cuba, Bebbington, Rogan, \& Millones, 2014; Okuthe, 2015; Plänitz \& Kuzu, 2015).

The literature largely agrees that globally, people living in extractive areas are not satisfied with the benefits they derive from resource extraction (Esteves, 2008; Sawyer \& Gomez, 2012). Local populations have often expected that the extraction of resources would not displace them from their traditional livelihood activities. However, extractive companies have largely failed to meet this expectation, leading to different interest groups emerging at different levels to negotiate on behalf of extraction-affected communities and indigenous populations. The negotiation processes have often resulted in conflicts and civil wars between disgruntled local populations and extractive companies in many extractive countries, especially those in Africa (Global Witness, 2007; O'Faircheallaigh, 2013; Obi, 2014). In Sierra Leone, the 1990 to 2000 civil war was largely associated with diamond mining where illegal diamond trade and export was the main sources of financing the war (Maconachie \& Binns, 2007). Obi (2014) also associated the recurring conflicts in the Niger Delta Region to the presence of oil and gas production in the region.

The occurrence of these conflicts has been largely attributed to imbalance between the resource extraction and the benefits to local population whose livelihoods and social conditions are affected by extraction (Obi, 2014). Gary and Karl (2003) and Maconachie et al. (2014) observed that the rights of local populations have often been tampered with, resulting in adverse environmental impact, poor compensations, poor benefit sharing, limited employment and development in resource extraction areas. In Nigeria for instance, multinational oil companies 
(MNOCs) have received severe criticism by both local and international pressure groups for engaging in unwholesome health, safety and environmental practices resulting in widespread ecological disturbances. As a result, protests from host communities have escalated into an all-out assault on oil companies and their workers leading to destruction of both onshore and offshore oil facilities and infrastructure (Bannon \& Collier, 2003; Dabup, 2012; Obi, 2014). Dabup (2012) confirms that in some instances, shutting downs oil wells and recurrent cases of kidnapping of workers by rebel groups occur in the Niger Delta Region.

From the actor-oriented theoretical approach, the paper examines the development of local actors in the nascent oil sector in Ghana and how these actors negotiate for their respective benefits from the oil resource. Proponents of the extractive led development of local populations have often argued from the liberal economic theoretical perspective that resource extraction will automatically trickle down associated benefits to local populations through national and sub-national structures (Campbell, 2001). In liberal economic theory, it is assumed that the presence of extractive industries in rural and remote regions will invariably benefit local population since the extractive industries would employ locals and pay them higher wages than their traditional economic activities. The literature however demonstrates that the liberal economic perspective has not yielded the expected benefits to local population. This has resulted in the several agitations and conflicts between extractive companies and local populations across extractive countries (Bunker, 1984; Bannon and Collier, 2003; Barrow, 2010; Bebbington, Cuba et al., 2014; Bond, 2014; Cuba, Bebbington et al., 2014; Obi, 2014).

Departing from the liberal economic theory is the actor-oriented theory which has been applied extensively in contemporary research in the extractive sector (Long, 2001; Obi, 2003; Laube, 2007; Tsuma, 2009; Mahmood and Humphrey, 2012; Islam, Kimihiko et al., 2014). The term actor has become common in the extractive sector literature and societal negotiation for local benefits. Actors are defined as persons, groups, organizations that are capable of making decisions and acting in a more or less coordinated way (Burns, Baumgartner et al., 1985; Herman, 2005). In other words, they are action-units, individuals or groups who are driven by either common or competing interest in any given phenomenon (Long, 2001; Laube, 2007; Tsuma, 2009).The actor-oriented paradigm unlike the liberal economic perspective embraces the roles played by individual and group actors in determining development outcomes. Spearheaded by Norman Long (1990) he argued that, although it may be true that certain important structural changes result from the impact of outside forces (controlled by the market or the state), it is theoretically unsatisfactory to base one's analysis about social change on the concept of external 
determination of the outcomes of development (Long, 1990).Long (1990), argued that social actors are not simply seen as disintegrated individuals without interests, nor are they passive recipients of outside interventions, but are active participants who process information and strategise in their dealings with various local actors as well as with outside institutions and personnel to influence change. He further argued strongly that the presence of any development intervention cannot be imposed from outside but depends on the interactions, negotiations, and struggles that take place between several kinds of actors in a given society. In his analysis of the political economy of the Nigerian oil sector, Obi (2003), recognised the roles played by youth and women as actors not only at the local scene but also at the national level where they connect their interests to global level actors.

\section{Local Benefits Negotiation Strategies in Extractive Sector}

Literature has often described negotiation as events of diplomatic artistry or rational decision-making processes. However, in certain circumstances negotiations are undiplomatic (Lewicki, Barry, \& Saunders, 2007). All negotiations are similar in that they involve people taking initial positions, offering proposals to help resolve the conflict, making counter-proposals, offering concessions, and coming to an agreement. However, negotiations can be distinguished according to the strategy and tactics that are used to conduct them. Literature shows that different strategies have been employed by local actors globally in negotiating for local benefits from extractive resources. Most common negotiation strategies in the extractive sector include; contentious politics, social movement, political bargaining, strategic groups and networking among others.

Contentious political negotiation strategies have been used extensively by local actors in the extractive industry (Bannon \& Collier, 2003; Obi, 2003).It is the interaction process in which various actors make claims bearing on someone else's interest, in which governments or companies appear either as targets (Tilly, 2008; Tarrow \& Tilly, 2009). It is the use of disruptive techniques to make a political point, or to change government or company policy in line with the interest of local actors particular in the extractive sector (Bebbington, 2012). Examples of such techniques are actions that disturb the normal activities of extractive companies such as: demonstrations, riots, terrorism, civil disobedience, and even insurrection or revolution(Tilly, 2012). The use of contentious politics by disgruntled local populations has been documented in the extractive sector literature, particularly in Africa, Asia and Latin America (Akabzaa, 2000; Bannon et al., 2003; Bebbington, Humphreys, Bury, Lingan, Muñoz \& Scurra, 2008; Tsuma, 2009; Offiong, 2010; Ogula, 2012; O'Faircheallaigh, 2013; Cuba, et al., 2014; Obi, 2014; Owen \& Kemp, 2014). Contentious negotiation strategies have the advantage of drawing quick 
attention of extractive companies and national government to the interest of local actors due to the disruptive tendencies on operations and profit. Nonetheless, strict application of this negotiation strategy has been catastrophic and has not yielded much benefit to local actors in several extractive communities (Tsuma, 2009; Obi, 2014).

Social movement is another negotiation strategy employed by local actors in negotiating for benefits in the extractive sector. Social movement enhances local empowerment and citizen activism and provides support for local people to hold states accountable in resource management (Bebbington, Bebbington et al., 2008). Social movements have different motives, including but not limited to contesting colonization of extractive resources and protesting against activities that are inimical to livelihoods. Bebbington Cuba et al. (2014), observed that there might be different actors within social movement in the extractive sector which may act differently for different interests at any given time. Recent studies have shown that several civil rights movements, environmental and feminist movements, and revolts against authoritarianism have become common worldwide, especially in the extractive sector, and masses of people have been brought onto the streets demanding change in resource distribution (Tarrow, 1994; Global Witness, 2007; Bebbington, Humphreys Bebbington et al., 2008; Esteves, 2008; Tarrow \& Tilly, 2009; Tsuma, 2009; Barrow, 2010). Tarrow and Tilly (2009) noted that these actions sometimes succeeded and others failed. They, however, opined that even when such actions failed, their movements had lasting effects, and set in motion important political and international changes (Tarrow \& Tilly, 2009).

Strategic group and networking strategies are also employed by local actors in negotiating for benefits from the extractive sector. This perspective has been spearheaded by Evers and Benedikter (2009), where they defined strategic group as group of actors in a given social and geographic setting which are aiming at a similar approach or strategic plan of gaining access and control of environmental resources. Ever and Benedikter (2009), are of the view that whenever new resources are made available in a given context, different groups of actors emerge with an aim of gaining control of these resources.While popular class theory has either perceived resource struggle as being between elites or the higher class, strategic group theory sees the struggle not necessarily amongst the elite group. Strategic groups in the natural resource sector may form coalitions to gain control of the benefits and most importantly, the opportunity to restructure the patterns of resource exchange and distribution (Evers and Benedikter, 2009; Tsuma, 2009). Even though an alliance between strategic groups might produce favourable conditions for better benefits, this process may also provoke reactions, movements, uprisings 
and possibly a revolution, which indeed, is often the case for most developing oil producing countries (Gelb, 1988; Manzano, 2002; ECCR, 2010; Henstridge, 2012; O'Faircheallaigh, 2013). This strategy is often used by local groups such as youth groups, community development associations and non-governmental organisations (NGOs). This strategy enables them mobilise local citizens for collective actions to advocate for the rights of the local populations affected by resources extraction(Obi, 2003; Bebbington et al., 2008; Tsuma, 2009; Campbell, 2012; Bebbington et al., 2014).

Political bargaining is another strategy employed by local actors in negotiating for local benefits of resources extraction (Levinson, Smith \& Wilson, 1999; Lewicki, et al., 2007; Leigh, Thompson, Jiunwen, \& Gunia, 2010).The institutions that control the distribution of extractive resources and political power are created by political entrepreneurs through election by the local population. In pursuing their own interests, the political entrepreneurs engage in negotiations with local actors on mutual concessions to trade local benefits of extractive resources for votes (Doron \& Sened, 2001). In the extractive sector it is common for politicians to engage local populace in negotiation where the local populace is promised some forms of benefits from resources extraction in exchange of votes during elections (Doron et al., 2001; Bannon et al., 2003; Bebbington et al., 2008; Bebbington et al., 2014). Fisher and Ury (1981) supported by Adler and Elmhorst (2005), have described this type of negotiation as soft positional bargaining which emphasizes the importance of building relationships.

It is worth noting that, these negotiation strategies explained above are not mutually exclusive. Actors sometimes combine these strategies in one way or the other to achieve their targets. Whiles contentious political negotiation strategies are dominating in the literature as the most common strategy employed by local actors, strategies such as political bargaining and strategic groups networking are becoming common especially in democratic societies in developing countries. Social movement strategies are very common in Latin America and gaining grounds in Africa in recent times (Bebbington et al., 2014; Obi, 2014).

\section{METHODS}

The paper is purely qualitative and is based on case study of two key local actors in benefit negotiation in the coastal districts of the Western Region of Ghana. To better understand in detail how the various social groups (actors) interact and negotiate for benefits from the oil resources in Ghana, the case study qualitative method of inquiry was deemed appropriate. According to Thomas (2011), case study is a kind of qualitative research that concentrates on one thing or issue or phenomenon, 
looking at it in detail, and not seeking to generalise from it. His emphasis is that case study is about the particular rather than the general. Qualitative case study is viewed as an approach to research that facilitates the exploration of a phenomenon within its context using a variety of data sources (Baxter \& Jack, 2008). According to Thomas (2011), a case can be viewed as a situation/event. As an event, a case is about the happening and the set of circumstances that surround this happening. Therefore a case study is about explaining the interrelationships between the elements of your study taking evidence from your empirical work and making arguments to connect elements of your observation (Thomas, 2011). According to Baxter and Jack (2008), a case in short is the unit of analysis in conducting the research. From this background my case study is the negotiation processes of actors for local benefits from the oil and gas sector.

In order to determine specific events in which negotiations occurred or are ongoing between local actors, oil and gas companies and the state, I embarked on series of field visits to the six coastal districts of the Western Region. Upon series of discussions with community opinion leaders, district assemblies and Nongovernmental Organisations (NGOs), several events were found, which demonstrate how local actors had negotiated or are negotiating for benefits from the oil and gas industry. Two of these events that is, negotiation between youth groups and oil and gas companies as well as negotiation between fisher folks and oil companies were, however, selected purposively because they showed clear processes of negotiation among different actors. The two actor groups; the fisher folks and youth are unique and were assertive in their demands for local benefits.Each of the phenomena selected therefore represented a case study. In this regard, the multiple case approach was applied. According to Stake (2005) cited in (Thomas, 2011), whenever a number of cases have to be studied jointly in order to investigate a phenomenon, multiple case study approach has to be applied.

Data was collected as part of $\mathrm{PhD}$ thesis research in the area which lasted for about 18 months from January 2015 to December 2017. Different qualitative data collection strategies were employed. Key informants in each actor group were identified and several in-depth interviews were conducted among the key informants in the selected case studies. Table 1 shows distribution of the category of respondents in the two case studies. 
Table 1: Categories of respondents for the study

\begin{tabular}{|l|l|l|l|}
\hline Actor Category & \multicolumn{2}{l|}{ Respondent Sex } & Total \\
\hline & Male & Female & \\
\hline Fisher Folks & & & \\
\hline Canoe Owners and fishers & 6 & 2 & 8 \\
\hline Chief Fishermen & 6 & & 6 \\
\hline Leaders of Fish Mongers & & 6 & 6 \\
\hline $\begin{array}{l}\text { Executives of Ghana Canoe Fishermen Association at District } \\
\text { Level }\end{array}$ & 4 & 2 & 6 \\
\hline Fish Venders & 2 & 5 & 7 \\
\hline & & & \\
\hline Youth Groups & & & \\
\hline Executives of Ahanta Youth Association & 4 & 2 & 6 \\
\hline Executives of Nzema Youth Association & 5 & 2 & 7 \\
\hline Total & $\mathbf{2 7}$ & $\mathbf{1 9}$ & $\mathbf{4 6}$ \\
\hline
\end{tabular}

Source: Field Data, 2017

Five focus group discussions (FGDs) were held for fisher folks one each at Dixcove, Butre, Axim, Cape Three Points and Half Asini. Two FGDs were also held with the Nzema Youth Association and the Ahanta Youth Associations. Notwithstanding that each FGD was guided by structured questions, several follow-up questions were asked during the FGD to seek clarifications and to probe for further information from participants.

The two case studies were run concurrently and in-depth face-to-face interviews were conducted to respondents based on their availability. Interviews were conducted on each case until saturation levels reached and no further interviews were necessary to establish the cases. Detailed field notes were taken during interviews alongside tape-recording. The typed interviews were transcribed and thematically analysed. Analytical memos were developed out of the field notes to guide the structure of the paper. The results are presented in narratives to portray the voices of the respondents.

\section{RESULTS AND DISCUSSION}

This section presents detail rendition of how the two actor groups are negotiating for benefits from the oil and gas resources in the Western Region and the negotiation strategies they employ. The results are being discussed with reference to literature and the theoretical framework guiding the study. 


\section{Fisher Folks Negotiation for Oil and Gas Benefits}

Marine fishing is the main economic activity of the entire coastal districts in the Western Region employing about 35\% of inhabitants (Ghana Statistical Service, 2013). Ackah-Baidoo (2013), confirms this assertion and emphasised that fishing is the main driver of the local economy in the coastal communities in Ghana (AckahBaidoo, 2013).

Since oil production in 2010 however, several concerns have been raised by fisher folks on the entire coast of the Western Region. Ackah-Baidoo (2013), in particular reported on the growth of sargassum (free-floating seaweeds) as a result of the oil extraction. This according to her has adversely affected fishing. Although the blame of the decline in yield of fish harvest on oil production has been contested by the oil companies, fisher folks have constantly argued that their livelihoods are under threat. They indicated that fishing in deep sea waters now has several restrictions, as the oil companies have positioned several exploration and production oil vessels and rigs with buffer zones limiting the activities of fishing at sea. A 40-year old fisherman at Butre, expressed his frustration; "We used to travel every part of the sea for fish without anybody stopping us, but now because of their 'Apolo 2', we cannot move freely to search for fish" (Fisherman at FGD, June 2015).

Respondents also attributed the low harvest to the presence of the oil rigs which attract fishes because of the high lights installed on them. According to a 42 year old fisherman at Dixcove;

We agree that some times in the past, before oil production, the fish harvest could be low in some seasons and that is normal. Our concern is that since oil production started, we have witnessed a consistent decline and sometimes we find dead whales and sharks onshore. This was not happening before the oil discovery in our area. If the oil companies are denying our claim, why is it that similar things are not happening in Cape Coast or Accra where they also fish? (Chief fisherman at Dixcove, July 2015).

The main interest of fisher folks is to get alternative livelihoods to supplement fishing which has come under threat as a result of oil production. To achieve this interest, fisher folks are adopting different negotiation strategies. Strategic alliance and collaboration with civil society organisations has become a common approach. For instance, the District and Regional Canoe Fishermen's Councils have initiated a strong collaboration with the Friends of the Nation NGO to ensure that the

2 The respondents referred to the oil rigs at sea as 'Apolo' which according to them is a name adopted from fishermen in Cote D'Ivoire. 
concerns and interest of fisher folks are taken into consideration in the planning and budgeting of oil and gas companies as well as the government decentralised system. New negotiation strategies proposed are to ensure more collaboration with the oil and gas companies to plan and implement cooperate social responsibility (CSR) projects. The oil companies have agreed to initiate all CSR projects with the consent and inputs of fisher folks so that the fisher folks own the projects upon completion. NGOs such as the Western Region Coastal Foundation, Friends of the Nation (FoN) and United Civil Society Organisations for National Development (UCSOND) are providing technical support to fisher folks in this regard.

We think if the NGOs work closely with us to understand our needs, they can mediate our negotiations with the oil and gas companies. Our only problem is that some of the NGOs are supporting the oil and gas companies and promoting their interests. Anyway, we know the good ones and will collaborate with them to promote our interests (Mr Ansah a member of the Ahanta West branch of the Canoe Fishermen Council, June 2015).

The fisher folks have also resorted to political bargaining as a negotiation strategy with government. During the 2016 Presidential and Parliamentary elections, the fisher folks in the Ahanta-West Constituency accused the incumbent Member of Parliament (MP) for not championing their interests to the government and oil companies and therefore, vowed not to vote for him. Some leaders of the fisher folks openly campaigned against the MP and supported the opposition candidate in the election. The fisher folks had a series of meetings and discussions with the opposition candidate and he promised to champion their interests in parliament when voted for. He also promised to discuss the interests of fisher folks with the oil and gas companies so as to influence their decisions on investing in the coastal fishing communities.

The two main parliamentary candidates of NDC and NPP for the 2016 general elections met us on separate meetings to discuss their plans for fisher folks. The NDC candidate who was incumbent MP had failed us for 8 years. We were convinced with the NPP candidate's plans. He promised to help us gain better benefits from the oil resources. He promised to ensure that substantial amount of the oil revenue is invested on development of fishing communities in the Western Region. We trust the candidate and asked our members to vote for him (Mr. Kofi a member of the Ahanta West branch of the Canoe Fishermen Council, June 2015). 
Eventually, the opposition NPP candidate won the Parliamentary election. The hope of the fisher folks is that the MP would honour his promise and ensure maximum benefits from the oil and gas resources. While this political bargaining and lobbying are on-going, the fisher folks have vowed to use all possible means of negotiations to achieve their benefits from the oil industry.

So far, fisher folks have described their benefits from the oil resources as abysmal and highly insufficient to compensate for the losses they have incurred due to oil exploration and production. Respondent recounted some few benefits such as plastic chairs and flat screen televisions donated to some fishing communities during the 2010 and 2014 FIFA World Cup Tournament, scholarships for basic education and postgraduate studies, small-town water projects among others. Some of the fisher folks felt that the collaborative negotiation strategies are not yielding enough benefits as the oil companies are adamant to their requests. Some contentious negotiation strategies are being adopted by some fishermen in the area. Fishermen will intentionally encroach the buffer zones where the oil rigs are located with the intention of provoking the oil companies. The fishermen vowed to continue fishing near the rigs until the oil companies and government initiate appropriate platforms for fisher folks to negotiate. Some other fishermen are also considering forming a militia group to fight their cause. To corroborate this Tomo (2015) indicated that some youth fishermen had planned to form a rebel group called 'Cape Militia. Some of the fishermen at Cape Three Points stated;

We have seen in videos from the Niger Delta in Nigeria where communities affected by oil production have formed militia groups and as a result, they gain recognition and benefits from oil companies and government. We may consider such an option when the current situation continues where companies are ignoring our demands (FGD with Fishermen at Cape Three Points, $13^{\text {th }}$ June, 2015).

\section{Negotiation for Oil and Gas Benefits by Concerned Youth and Grassroots Movements}

The emergence of youth associations as actors in the negotiation for oil benefits on the coast of Western Region is an extension from the mining sector and is instigated by the growing general youth unemployment in Ghana, in particular the coastal communities (Ghana Statistical Service, 2014). Many of the youth became very happy when the oil was discovered in 2007 not only because of the potential revenue for the state, but largely because of potential job opportunities. Darkwah (2013), and the Friedrich-Ebert-Stiftung Ghana (2011), have noted high job expectations among the youth in Ghana particularly, those living along the coast of Western Region 
since the oil discovery and production in 2010. Darkwah (2013) noted a proliferation of specialised trainings for the youth which is organised by both local and foreign training institutions in anticipation of jobs in the oil and gas industry.

It is evident that the main interest of the youth in the coastal districts is to get jobs in the oil and gas sector. The fundamental question, however, is which areas in the oil and gas industry will the youth fit? Several analyses of local employment potentials of the oil industry in developing countries suggest that the sector requires special skills and expertise. But most often local indigenes lack such skills (Friedrich-Ebert-Stiftung Ghana, 2011; Darkwah, 2013; Cuba et al., 2014). The problem of who has the responsibility to develop the skills of local people to meet the requirement of the nascent oil industry in Ghana is still a subject of political debate. Ghana as part of its local content and local participation policy has mandated oil and gas companies to employ skilled local folks and transact business with those with appropriate documentations. But the oil companies have expressed concern about the lack of skills and competencies among local people and businesses, making it difficult to engage them in the industry.

Although several respondents alluded to the fact that they lack the requisite skills for employment in the oil industry, they were confident in getting menial jobs such as security and driving. Others were also optimistic that with training, they could develop relevant skills to meet the requirement of the oil industry. Some youth at Dixcove were very optimistic and stated;

We are not looking for technical jobs; after all we have not gone to higher schools. What we are sure is that we can do watchman, security and cleaning jobs in the oil companies' offices. These ones too we need so much skills and training? We are here and the companies bring watchmen and cleaners from Accra. Why can't they employ us and give us such training as they offer to those employed from outside our communities? (FGD, at Dixcove, 22/03/2016).

As a strategy of getting the attention of the oil companies and government, the youth in the coastal districts have resorted to the formation of youth associations and revival of old ones that had been dormant. The proliferation of youth associations to negotiate for benefits is largely due to the lack of trust of the youth in state regulatory agencies to seek the economic welfare of the youth. Peter, a 26-yearold and member of the Dixcove Youth Club indicated;

Since the oil discovery in 2007, we were promised that several jobs would come to our community and we the youth will get jobs. Since then we have seen nothing. All we see is that several people are employed from Accra 
and brought to work in the oil companies. The district assemblies and our chiefs are doing nothing to help us get our share from this oil. We therefore have to come together to fight our own cause (FGD at Dixcove, 23/01/2016).

Similar views such as the one expressed by Peter are held by several youth across the six coastal districts, leading to the formation of youth associations. At Half Assini in the Jomoro District, members of the Nzema Youth Association saw the need to revive their old but dormant association formed in 2008 to serve as a mouth piece for them to negotiate for special benefits from the oil industry. The formation of youth associations as actors in the local benefits negotiation is being encouraged by several other actors. The NGOs, the district assemblies, chiefs, and even the oil companies, see the formation of the youth associations as very relevant. The oil companies for instance, see the youth associations as strong forces for community development since the youth are the main active group in most of the communities. NGOs such as Friends of the Nation and UCSOND confirmed having to work closely with youth associations during community mobilisation and sensitisation on oil and gas issues. Obi (2003) observed that the youth are a critical factor in discussing development in the Nigerian oil sector because they represent the intelligentsia and future leaders of every community. Some of the youth associations are receiving support from the oil and gas companies in line with their requests. At Dixcove, the Youth Club received support from Tullow Oil Ghana and Kosmos Energy in their joint community development initiative to build a computer laboratory for training the youth in ICT skills for the oil industry. The youth also attributed the building of the Skills Training Centre at Takoradi Polytechnic to their constant advocacy for a special skills development for the oil industry.

It is worth noting that ethnic differentiations in the Western Region are reflecting in the development of youth associations. For instances, youth associations from the Ahanta ethnic group have the feeling that those of Nzema descent are more favoured by the oil companies. This view was openly expressed by some youth of the Ahanta communities.

We the youth from the Ahanta Areas have been left out in this whole oil business. When it comes to where the oil is found, we believe that it is closer to the Ahanta areas. For instance, they always refer to areas such as Cape Three Points as the location of the oil and Cape Three Points is in Ahanta land. Why should it be that they are not prioritising our areas? We believe that current leaders in government managing the oil industry are from the Nzema areas and are working for them (FGD, Cape Three Points, 07/02/2016). 
Literature acknowledges that most youth activism have taken ethnic identity. In most cases the youth protest against marginalisation and resistance against any form of exclusion of their ethnic groups from the benefits of extractive resources (Obi 2003, Tsuma 2009, Obi 2014). The formation of the National Youth Council of the Ogoni People and Ijaw Youth Congress are examples of such ethnic biased youth groups formed for negotiating benefits for the local folks in Nigeria (Obi 2003).

\section{CONCLUSION AND POLICY RECOMMENDATIONS}

The paper has provided evidence of negotiations taking place between local actors and oil and gas companies. The findings confirm that local actors are employing different strategies in their negotiations. From the actor oriented theoretical perspective it is clear from the study that although the state and companies through policies and institutions may facilitate the process of local benefits to local population, the direct actions or inactions of the local actors themselves will determine when and how those benefits will be accrued and distributed. As noted by Long (2001), local actors are not passive recipients of development interventions but are participants capable of influencing the decisions of companies through series of negotiation strategies.

It is worth arguing, based on the findings that the presence of proactive local actors championing local benefits negotiations in the Western Region signifies the existence of an organised social and political system, conducive for dialogue and community engagement. Although the study found several collective actions by local actors which can be described as contentious, such actions as explained in the paper have not assumed violent proportions comparable to those for instance, in the Niger Delta in Nigeria. It is therefore important for the oil and gas companies and government to recognise this as opportunity to create the enabling negotiation space to stimulate healthy negotiation that will be beneficial to local actors, oil and gas companies and the state. It is however noted that, the absence of state policy to mediate local benefits negotiations between oil and gas companies and local actors gives room for unregulated negotiations which may turn the current very less violent negotiations process between local actors, oil and gas companies and the state into violent ones.

Therefore, as Ghana celebrates its new oil and gas discovery and associated potentials for national development, it is important to recognise the interests of local population and actors affected by oil and gas production. Prioritising these interest groups by both oil and gas companies and government will reduce the current feeling of neglect by the local population in the Western Region. It will 
also provide opportunity for healthy negotiations between local actors and oil industry players, a situation which is not common in many oil producing countries in developing countries. State coherent policies and structures to mediate the negotiation processes between local actors, companies and the state are therefore recommended to avoid violent conflicts in the Ghana oil and gas sectors. More sensitisations need to be given to local actors to understand the oil and gas industry so as to reduce the high expectations for local benefits. The work of civil society is therefore highly recommended to support build a strong local actor population capable of negotiating professionally for local benefits in the oil and gas sector.

\section{REFERENCES}

Ackah-Baidoo, A. (2013). Fishing in troubled waters: oil production, seaweed and community-level grievances in the Western Region of Ghana. Community Development Journal, 48(3), pp. 406-420.

Adler, R.B. and J. M. Elmhorst (2005). Communicating at work: Principles and practices for business and the professions, Boston, McGraw-Hill, pp. 23-28.

Akabzaa, T.M. (2000). Boomand Dislocation;The Environmental and Social Impact of Mining in the Wassa West District of Ghana. Accra, Third World Network Africa.

Bannon, I. and Collier P. (2003). Natural Resources and Conflict: What We Can Do. Natural Resources and Violent Conflict: Options and Actions. Washington, DC, World Bank: pp. 1-16.

Barrow, C.J. (2010). How is environmental conflict addressed by SIA? Environmental Impact Assessment Review, 30(5), pp. 293-301.

Baxter, P. and Jack, S. (2008). Qualitative Case Study Methodology: Study Design and Implementation for Novice Researchers. The Qualitative Report Volume, 13(4), pp. 544-559.

Bebbington, A. (2012). Underground political ecologies: The second Annual Lecture of tthe Cultural and Political Ecology Specialty Group of the Association of American Geographers. Geoforum, 43(6), pp. 1152-1162.

Bebbington, A., Humphreys Bebbington, D., Bury, J., Lingan, J., Muñoz, J. P., \& Scurra, M. (2008). Mining and Social Movements: Struggles Over Livelihood and Rural Territorial Development in the Andes. World Development, 36(12), pp. 28882905.

Bebbington, A.J., Cuba, N., and Rogan, J. (2014). Visualizing competing claims on resources: Approaches from extractive industries research. Applied Geography, 52(o), pp. 55-56. 
Bond, C. J. (2014). Positive peace and sustainability in the mining context: beyond the triple bottom line. Journal of Cleaner Production, 1(33), pp. 1-10.

Bouten, L., Everaert, P., Van Liedekerke, L. De Moor, L., and Christiaens, J. (2011). Coporate social responsibility reporting: A comprehensive picture? Accounting Forum, 35(3), pp. 187-204.

Bunker, S.G. (1984). Modes of extraction, unequal exchange, and the progressive underdevelopment of an extreme periphery: the Brazilian Amazon, 16001980. American Journal of Sociology,89, pp. 1017-1064.

Burns, T.R. and Baumgartner T.M. (1985). Man, decisions, society. The Theory of actorsystem dynamics for social scientists. Gordon and Breach Science Publishers, p. 342.

Campbell, B. (2001). The Role of Multilateral and Bilateral Actors in Shaping Mining Activities in Africa. Mining, Development and Social Conflicts in Africa. Accra, Third World Network Africa.

Campbell, B. (2012). Corporate Social Responsibility and development in Africa: Redefining the roles and responsibilities of public and private actors in the mining sector. Resources Policy, 37(2), pp. 138-143.

Cuba, N., Bebbington, A., Rogan, J., and Millones, M. (2014). Extractive industries, livelihoods and natural resource competition: Mapping overlapping claims in Peru and Ghana. Applied Geography, 5(3), pp. 1-12.

Dabup, N., and Lami, A. (2012). Health, Safety and Environmental Implications in Nigeria's Oil and Gas Industry. PhD Thesis, Nelson Mandela Metropolitan University

Darkwah, A.K. (2013). Keeping hope alive: an analysis of training opportunities for Ghanaian youth in the emerging oil and gas industry. International Development Planning Review, 35(2), pp. 119-134.

Doron, G. and Sened, I. (2001). Political Bargaining; Theory, Practice and Process. London, SAGE. pp. 23-27

Ecumenical Council for Corporate Responsibility-ECCR (2010). Shell in the Niger Delta: A framework for change: Five case studies from civil society, ECCR.

Edem, R. (2011). The Expected Impact of the Oil Discovery in Takoradi on Land Use Patterns and Growth on the City. Kumasi, Kwame Nkrumah University of Science and Technology, Ghana. BSc Thesis.

Esteves, A.M. (2008). Evaluating community investments in the mining sector using multi-criteria decision analysis to integrate SIA with business planning. Environmental Impact Assessment Review, 28(4-5), pp. 338-348. 
Evers, H.D. and Benedikter S. (2009). Strategic Group Formation in the Mekong Delta - The Development of a Modern Hydraulic Society, Center for Development Research, Department of Political and Cultural Change, University of Bonn.

Fisher, R. and Ury W. (1981). Getting to yes, New York: Penguin, pp. 24-31.

Friedrich-Ebert-Stiftung Ghana (2011). Youth and Oil and Gas Governance in Ghana: Nationwide Survey, Friedrich-Ebert-Stiftung Ghana.

Gary, I. and Karl, T.L. (2003). Bottom of the barrel: Africa's oil boom and the poor. Catholic Relief Services, USA.

Gelb, A.H. (1988). Oil Windfalls: Blessing or Curse? New York, Oxford University Press.

Ghana Statistical Service (2013). Population and Housing Census, Ghana Statistical Service.

Ghana Statistical Service (2014). Ghana Living Standards Survey Round 6, Ghana Statistical Service.

Global Witness (2007). Oil and Mining in Violent Places: Why voluntary codes for companies don't guarantee human rights, Global Witness

Henstridge, M. (2012). Enhancing the Integrity of the Oilfor Development Programme:

Assessing vulnerabilities to corruption and identifying prevention measures-case studies of Bolivia, Mozambique and Uganda. Norad Report 7/12 Discussion, Norwegian Agency for Development Cooperation-NORAD. 7/12: 77.

Herman, L.M. (2005). Actor analysis for water resources management: Putting the promise into practice. Netherlands, Eburon Publishers.

Idemudia, U. (2007). Corporate Partnerships and Community Development in the Nigerian Oil Industry: Strengths and Limitations. United Nations Research Institute for Social Development (UNRISD), Business and Regulation Programme. Paper Number 2.

Islam, K.K., Kimihiko, H., Tani, M., Krott, M., and Sato, N. (2014). Actors' Power, Livelihood Assets and Participatory Forestry in Bangladesh: Evidence from the Sal Forests Area.Open Journal of Forestry, 4, pp. 1-9.

Ite, E.U. (2007). Changing Times and Strategies: Shell's Contribution to Sustainable Community Development in the Niger Delta, Nigeria.Sustainable Development, 15 (1), pp. 1-14.

Laube, W. (2007). Actors, Structures and Institutional Change: External Interventions and the (De) Institutionalization of Local Natural Resource Regimes in Northern Ghana. University of Bonn, Center for Development Research (ZEF). 
Leigh L. Thompson, Jiunwen Wang and Gunia, B. C. (2010). Negotiation. Annual Reviewof Psychology, 61 (1), pp. 491-515.

Levinson, J.C., Smith, M.S.A. and Wilson, O.R. (1999). Guerilla negotiating: Unconventional weapons and tactics to get what you want. New York: John Wiley.

Lewicki, R.J., Barry, B. and Saunders, D.M. (2007). Essentials of Negotiation (4th Ed.). Boston: McGraw-Hill.

Long, N. (1990). From Paradigm Lost to Paradigm Regained.European Review of Latin American and Caribbean Studies, 49, pp. 1-23.

Long, N. (2001). Development Sociology: Actor Perspective. London Routledge.

Mahmood, M. and J.K. Humphrey (2012). Stakeholder Expectation of Corporate Social Responsibility Practices: A Study on Local and Multinational Corporations in Kazakhstan.Corporate Social Responsibility and Environmental Management, 20, pp. 168-181.

Maconachie, R., and Binns, T. (2007). Farming miners' or 'mining farmers: Diamond mining and rural development in post-conflict Sierra Leone. Journal of Rural Studies, 23(3), pp. 367-38o.

Manzano, R. (2002). Natural resources Neither Curse nor Destiny. Washington DC, Standford University and World Bank.

Mohammed, A.S., Kpieta, B.A. and Owusu-Sekyere, E. (2014). Oil and Gas Production,

Environmental Health and Livelihood Vulnerability in the West Coast of Ghana. African Journal of Sustainable Development, 4(2), pp. 157-173.

Nkrumah, D. Aklorbortu, M.D. and Suazo, K. (2008, 15-03-2008). Drilling of Oil in Commercial Quantity: We have done it before. Daily Graphic, pp. 1-32.

O'Faircheallaigh, C. (2013). Extractive industries and Indigenous peoples: Achanging dynamic? Journal of Rural Studies, 30(o), pp. 20-30.

Obeng-Odoom, F. (2013). Resource curse or blessing in Africa's oil cities? Empirical evidence from Sekondi-Takoradi, West Africa. City, Culture and Society, 4(4), pp. 229-240.

Obi, C. (2003). Emergent Actors in Africa Political Economy: A study of Youth Movements in the Oil Producing Communities of the Niger Delta. Emergent of Actors in Africa Political Economy. K. Mochizuki, Institute of Developing Economies: pp. 43-72.

Obi, C. (2014). Oil and conflict in Nigeria's Niger Delta region: Between the barrel and the trigger. The Extractive Industries and Society, 3(1), pp. 1-7. 
Offiong, J. (2010). Oil and gas industry in Nigeria: The paradox of the black gold. Environment and Social Justice: An International Perspective (Research in Social Problems and Public Policy). D.E. Taylor, Emerald Group Publising Limited. 18, pp. 323-349.

Ogula, D. (2012). Corporate Social Responsibility: Case Study of Community Expectations and the Administrative Systems, Niger Delta. The Qualitative Report, 17(37), pp. 1-28.

Okuthe, I.K., (2015). Environmental and Social challenges of oil and gas exploration in Kenya. International Journal of Innovation and Scientific Research, 17(1), pp. 164-174.

Owen, J.R. and D. Kemp (2014). Mining and community relations: Mapping the internal dimensions of practice.The Extractive Industries and Society, 1(1), pp. 12-19.

Owusu, A.Y. (2014). The Dimensions of Oil Discovery in Ghana: What can it do for the Economy and the People? Managing Ghana's Oil Boom for Structural Transformation. In Aryeetey, E. Osei R.D. and Quartey. P. (Ed). Legon, Accra, Ghana, Institute of Statistical, Social and Economic Research (ISSER): 225-254.

Owusu, G. and H.B. Boatemah (2014). Oil and the Western Region: Implications for Regional and Local Development. Managing Ghana's Oil Boom for Structural Transformation (pp. 49-76). In Aryeetey, E. Osei R. D. and Quartey. P. (Ed). Legon, Accra, Ghana, Institute of Statistical, Social and Economic Research (ISSER): 225-254.

Plänitz, E. and Kuzu, D. (2015). Oil Production and the transformation of livelihoods of communities in Ghana, Institute for Statistical, Social and Economic Research (ISSER) at the University of Ghana.

Pyagbara, L.S. (2007). The Adverse Impacts of Oil Pollution on the Environment and Wellbeing of a Local Indigenous Community: The Experience of the Ogoni People of Nigeria International expert group meeting on indigenous peoples and protection of the environment. Khabarovsk, Russian Federation, United Nations.

Tarrow, S. (1994). Power in Movement. Cambridge: Cambridge University Press.

Tarrow, S. and Tilly, C. (2009). Contentious Politics and Social Movements. Oxford: Oxford University Press.

Thomas, G. (2011). How to do your Case Study: A Guide for Students \& Researchers. London, Sage Publications Inc.

Tilly, C. (2008). Contentious Performances. Cambridge: Cambridge University Press.

Tilly, C. (2012). Social Movements 1768-2012. London: Taylor \& Francis LTD. 
Tomo, K.B. (2015). Ghana's Oil Find and Real Community Expectations; The Role of Trans-National Corporations, School of Applied Social Studies. Robert Gordon University, Aberdeen, Robert Gordon University. Master of Science Thesis.

Tsuma, W. (2009). Actors, Alliances and Power in Negotiations, Understanding Unequal Distribution of Benefits in Tarkwa's Gold Mining Area of Ghana ZEF. Bonn, University of Bonn. PhD Thesis.

Yakovleva, N. (2011). Oil pipeline construction in Eastern Siberia: Implications for indigenous people.Geoforum, 42(6), pp. 708-719.

Yalley, P.P. and Ofori-Darko (2012). The Effects of Ghana's Oil Discovery on Land and House Prices on Communities Nearest to the Oil field in Ghana: Case Studies of Kumasi and Sekondi-Takoradi. Procs 4th West Africa Built Environment Research (WABER) Conference. Abuja, Negeria: pp. 1443-1454. 